\title{
How the Dutch plan to stay dry over the next Century
}

\author{
Marcel J.F. Stive ${ }^{1}$, Louise O. Fresco ${ }^{2}$, Pavel Kabat ${ }^{3}$, Bart W.A.H. Parmet ${ }^{4}$, Cees. P. Veerman ${ }^{5}$
}

Over two-thirds of the Netherlands' economy and half its population is below sea level. The Dutch government recently set out far-reaching recommendations on how to keep the country flood-proof over the next century given the likelihood of rising sea levels and river flows. This paper explains the recommendations, which are based on a gradual upgrading of safety standards in the light of economic growth and group casualty risk, together with triggers provided by debates and data on climate change. It concludes that protection is feasible both technically and economically, costing up to $€ 3$ billion a year, and that the approach could be useful for other low-lying areas.

The Netherlands is a densely populated country with a prosperous, open economy situated largely in coastal lowlands. The Dutch North Sea coast is about $350 \mathrm{~km}$ long and most of the population lives directly behind the coast in low-lying areas below sea level. This region is the centre of the nation's economy, with nearly 9 million people protected by dykes and dunes along the coast, main rivers and lakes, and roughly $65 \%$ of gross national product - around $€ 350$ billion - generated here. The major harbours and airports on or near the North Sea are vital nodes in the country's international transport network as well as important locations for the goods and services industries.

The Netherlands has a long and varied history of coastal and river flood management. The anticipation of accelerated climate change during the twenty-first century has renewed the demand for sustainable solutions to coastal vulnerability.

In September 2008, a committee set up by the government in September 2007 delivered a number of recommendations on making the country flood-proof for the next century (Delta committee, 2008). In addition to flooding it also considered river levels and fresh water availability. This paper presents and discusses some of the findings.

\section{Potential damage from flooding}

The Central Bureau for Statistics Netherlands estimates the national wealth as five times the national income, without taking account of ecological, landscape and cultural values (Van Tongeren and Van de Veen, 1997). Based on this definition, Dutch national wealth was about $€ 2750$ billion in 2007. Since an estimated $65 \%$ of this wealth lies in flood-prone areas, the total wealth potentially under threat due to flooding is of the order of $€ 1800$ billion.

The actual economic damage from the failure of the flood protection system has been estimated as €1050 billion for each individual area protected by dykes - referred to as 'dyke rings'. There are 53 dyke rings in the Netherlands, with protection levels at $90 \%$ probability of resisting design water levels that vary between 1:10 000 and 1:1250 probability a year (see Figure 1). This implies flooding probability varies between 1:100 000 and 1:12 500 a year. With the identification of failure mechanisms other than wave overtopping and/or overflow, notably piping (e.g. New Orleans), there is now a strong debate on how realistic these flooding probability figures actually are. As such, the government's Delta committee (2008) suggests that the design water level probabilities should be interpreted as flooding probabilities for the time being. Recent insights of flooding scenarios (Jonkman 2007, 2008) indicated that it is most unlikely that the major dyke rings will be inundated completely. The location of a dyke and the physical circumstances under which it is breached will make a marked difference in the resulting economic damage. Also, the damage caused by a flood depends on the size of the area inundated, the water depth in that area and the duration of the episode.

Aerts et al. (2008) estimated the economic damage from flooding through all dyke rings as approximately $€ 190$ billion, based on differentiation according to water depth per dyke ring. This concerns both direct and indirect damage. The estimated future potential damage would increase to $€ 400-800$ billion in 2040 and $€ 3700$ billion in 2100 in the absence of any measures, given a sea level rise of $0.24-0.60 \mathrm{~m}$ in 2040 and 1.5 $\mathrm{m}$ in 2100 .

\footnotetext{
${ }^{1}$ Delft University of Technolgy

${ }^{2}$ University of Amsterdam

${ }^{3}$ Wageningen University

${ }^{4}$ Ministry of Infrastructure

5 Tilburg University
} 
The factors that govern calculations of estimated future potential damage are economic growth combined with indirect damage. Prior to hurricane Katrina, potential damage in New Orleans was estimated at US\$16.8 billion or $€ 12.3$ billion. After the 2005 storm hit, direct damage to dwellings, government buildings and public infrastructure alone was US\$27 billion or $€ 19.7$ billion (IPET, 2008), illustrating that it is essential to update economic growth and indirect damage figures regularly.

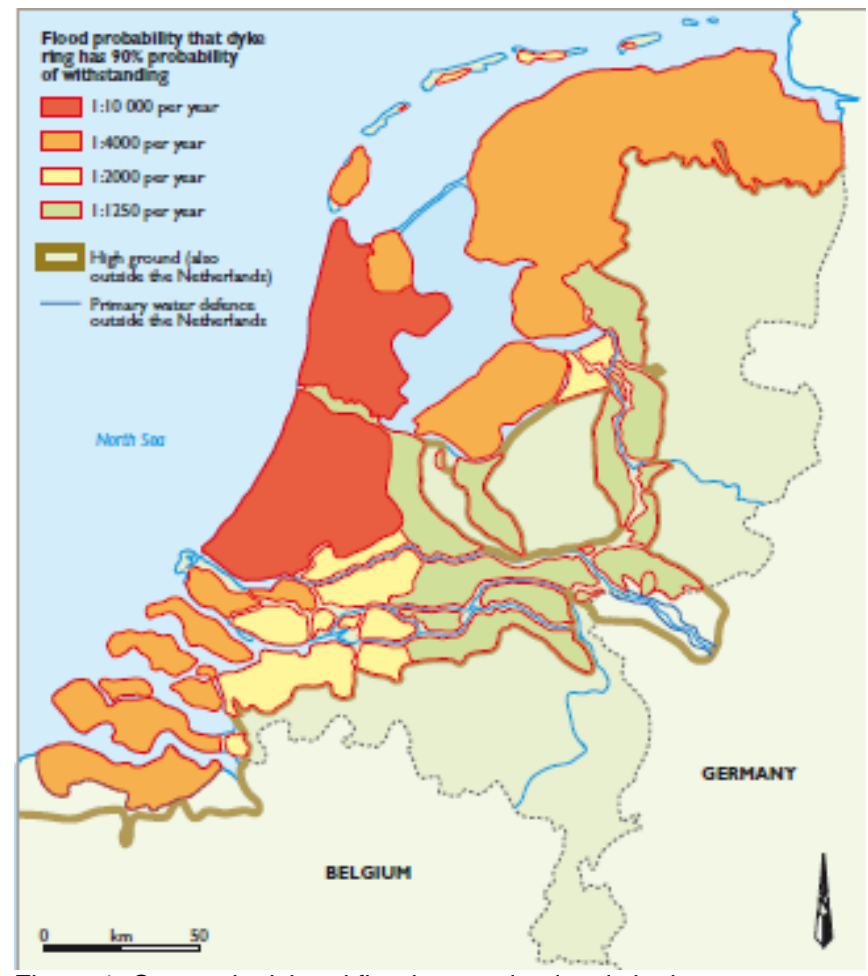

Figure 1: Current legislated flood protection levels in the Netherlands' 53 "dyke rings" - more economically important areas have up to four times the protection of some rural areas

\section{Paradigm shift}

Implementing the Delta committee's recommendations will require a paradigm shift in the Dutch approach to water and coastal management. Whereas in the past the challenge was formulated to 'fight' the forces of nature, it is now recognised that many issues other than protection against flooding have to be accommodated - particularly ecological issues.

Water and coastal management have become interdisciplinary as well as transdisciplinary (Waterman, 2008). Some of the issues and dilemmas involved in this challenge are illustrated by the following examples.

\section{Working with nature}

In a critical evaluation of the morphological, ecological and socio-economic effects of the Delta project following the 1953 flood disaster, Saeijs et al. (2004) advocated working with nature in any future flood protection project in estuarine and coastal environments. A number of their recommendations exemplify this: 'If there is

still is a choice, leave untouched estuaries and deltas alone'; 'If there is already a history of human intervention, try to adopt the most flexible approaches to safety and development'; and 'Reversible and local measures within the limits of the natural processes are preferable'.

The recommendations regarding working with nature are in line with today's policy, for example maintaining the coastline with 'soft' solutions rather than hard concrete barriers. Nevertheless, implementing the recommendations appears to be complex. For instance, sea dykes may hamper natural processes, but from an economic viewpoint it is generally not justifiable to remove dykes, let alone from a socio-emotional perspective.

The complexity is further illustrated by the conclusions of Jonkman et al. (2005), which set out lessons for the Netherlands from the New Orleans flood disaster of 2005. This highlighted a tendency in Dutch policy to head towards the US model of mitigating consequences instead of strengthening flood defences, with prevention of floods receiving gradually and relatively less attention. Arguing that protection standards were over 40 years old and had not evolved with the increase of economic value of protected areas over time, and that societal risks associated with flood defences on a national scale were larger than in other aspects of Dutch society (Ten Brinke and Bannink, 2004), the authors concluded a fundamental debate on required safety levels of Dutch flood defences was necessary.

\section{Interdisciplinary and transdisciplinary approaches}

Coping with such dilemmas is an example of the major challenges currently facing the Dutch government. It illustrates that 'working with nature' does not just imply using natural sciences - it involves a range of different disciplines and requires a transdisciplinary approach.

The water problem in the Netherlands is unstructured: different actors have different perspectives, uncertainties are large and relevant knowledge is under debate. Typical characteristics that, according to Hoppe and Huijs (2003), ask for a transdisciplinary approach are a specific type of interdisciplinarity, transgressing borders between disciplines and integrating knowledge and perspectives of different scientific disciplines and non-scientific sources (Pereira and Funtowicz, 2005). An example of the practical implications for coastal engineers is formulated by Kamphuis (2006). 
'They must participate. They need to understand, discuss and explain uncertainties openly and clearly. They must realise that they do not provide some final proof, but only the best possible insight for an optimum solution. They must also recognise that they are not in competition with the approval process, but complementary to it'.

The approach is of even more importance in the view of the long-term perspective that needs to be the basis of any coastal and water management recommendations, because many physical features, such as dune ranges and estuaries, as well as socio-economic values change at the scale of centuries.

\section{Background to committee}

The recent Netherlands Delta committee was not established in response to a flood disaster, unlike previous state committees, which were established after severe floods hit the country in 1916 and 1953. It was triggered by the debate in the Netherlands on the delay in bringing safety up to the standards laid down in the Flood Defences Act (Kingdom of the Netherlands, 1996), the 2005 flooding of New Orleans and the debate on climate change.

The committee's work demonstrates the importance of a wide-ranging, longterm preventive approach. Its recommendations are based on the necessity to upgrade safety standards in the light of economic growth and group casualty risk, meaning that the country has 'more to lose'.

The committee underpinned the basic risk approach introduced by the first Delta committee of 1953. The most important conclusion is that the protection of the Netherlands, with two-thirds of its economic value and half of its population positioned below sea level, is feasible, both technically and economically, if planned in a long-term and flexible manner. Such an approach could provide useful elements for other lowlying areas.

\section{Risk approach}

The mega structures, such as storm surge barriers, introduced by the first Delta committee were innovative and impressive, but what may prove to be the most visionary aspect of the Delta works is the statistical approach that guided the designs. How high should the levees be built? How strong should a surge barrier be? The Dutch decided to base their answers to these questions not merely on the fact that storms are destructive and the Netherlands low, but also on quantitative economics. With the help of renowned Dutch mathematician David Van Dantzig (1956), the 1953 task force calculated safety levels using an equation that is now widely used by most engineers

$$
\text { risk = probability of failure } \times \text { projected cost of damage }
$$

This kind of risk analysis is common today in fields like nuclear power, aerospace and chemical manufacturing.

Back in the 1950s, however, accounting for the projected cost of damage when developing flood protection was novel. The power of the simple formula is that it produces economically rational publicsafety decisions: less value, less protection (costs of human casualties are not taken into account directly). Dutch law now requires the principle to be used to determine the strength of flood defences throughout the country.

In the case of the dyke ring protecting the province of South Holland, an economically vibrant area, against flooding due to extreme storm surge levels and/or extreme river discharges, a safety level of 1:10 000 is called for. More rural parts of the country are required to have safety levels of just 1:1250 or lower (see Figure 1). The underlying principle that leads to the variable levels of protection is Van Dantzig's economic optimisation criterion (Van Dantzig, 1956): strive towards minimal societal costs summing the protection investment and the potential estimated damage.

The corollary is that, although not all Dutch citizens may be aware of it, their government has accepted even legislated - unequal protection, or what engineers euphemistically call 'differentiation', based on the fact that all places cannot be protected up to the same standard and individual cost must be balanced against collective cost.

The USA certainly has variable protection levels throughout the country, but there is a difference between de facto disparity and an explicit government policy of inequality. Imagine if the US Congress or the Army Corps of Engineers were to recommend protecting the French quarter and downtown New Orleans at the 1:10 000 year level while giving less economically productive areas such as St Bernard Parish only a 1:100 year level of protection. Applying the Dutch model of risk-based design would be a political nonstarter, if not unconstitutional, and the efforts of the Army Corps of Engineers would in no time be halted by an army of lawyers.

\section{Updating standards}

The standards for safety from flooding based on the risk approach need rethinking, however, because both individual and group risk for casualties (deaths) due to flooding is much higher than due to other 
external risks (Jonkman 2007, 2008). That is why the Delta committee recommends opting for an increase in protection level with a factor of 10 , which is estimated to be a minimum 'no regret' level to reduce the casualty risk. This implies that interpreting present legal risk levels as probabilities of flooding based on a full-risk approach should vary from 1:100 000 to 1:12 500 a year.

\section{Climate change}

To anticipate long-term developments, the Delta committee sought to base its recommendations on the most recent scientific findings. The committee therefore asked a team of renowned national and international climate experts (among whom were Intergovernmental Panel on Climate Change (IPCC) authors who contributed to the recent fourth assessment report; see Katsman et al., 2011; Kok et al., 2008; and Vellinga et al., 2008) to deliver the best possible estimates of the expected global and regional (i.e. North Atlantic Ocean) sea-level rise and rainfall intensity that give rise to river discharge changes.

Their updated climate model results resulted in a probable range of upper boundaries for the expected climate changes: sea-level rise along the coast in the year 2100 could reach as high as $0.65-1.3 \mathrm{~m}$ relative to 1990, including isostatic movement and subsidence. However, it is clear that the upper boundaries do not represent the most likely probable situation in 2100 , as has also been stated by the Royal Netherlands Meteorological Institute.

The figure is nevertheless relevant because it represents an extreme case against which the committee could try to answer the most relevant issue, namely: can the Netherlands be kept flood-proof under the most extreme scenario? That is why in the committee's advice the high-end scenarios were considered, so that a convincing and science-based positive answer ('yes') could be given.

\section{Committee recommendations}

A total of 12 recommendations were formulated: three generic and nine regional as follows (Delta committee, 2008). Figure 2 shows the regional locations and Figure 3 provides a graphic of the recommenddations.

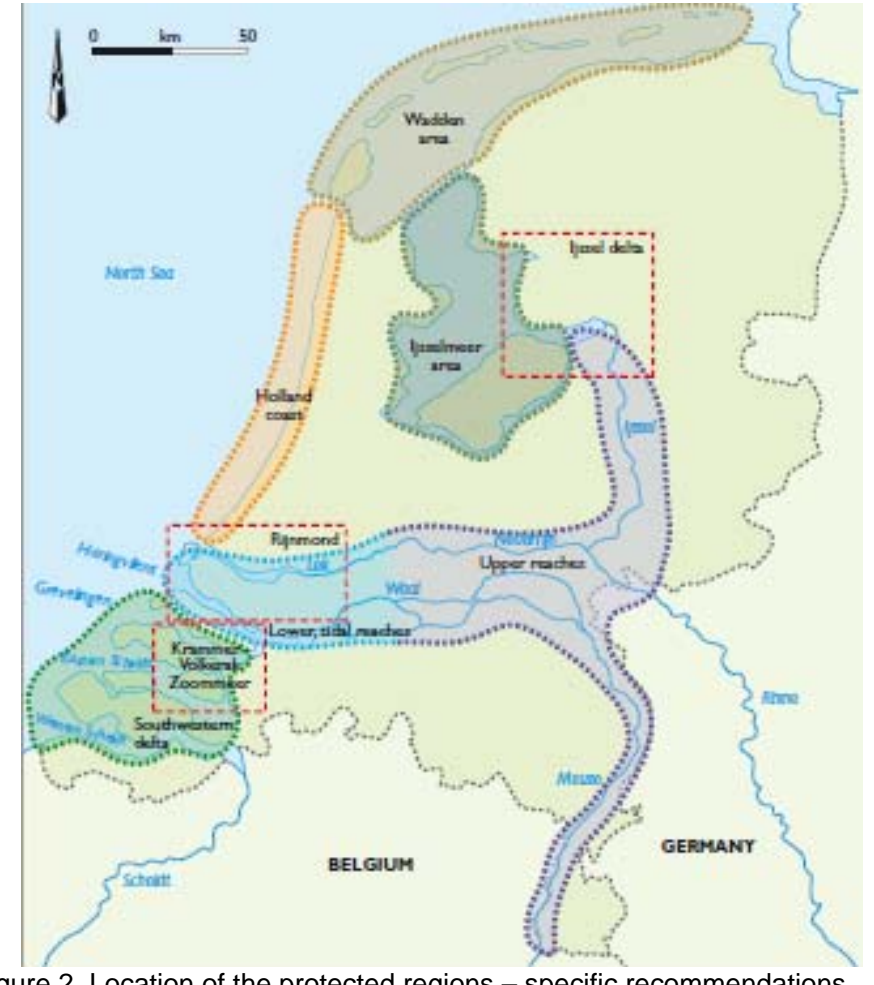

Figure 2. Location of the protected regions - specific recommendations have been produced for each

\section{Standards of flood protection}

Until 2050, the present standards of flood protection of all dyke rings must be improved by a factor of 10 . To that end, new standards must be set as soon as possible (around 2013). In some areas where even better protection is needed, a 'Delta dyke' concept is promising these dykes are either so high or so wide and massive that there is virtually zero probability they will suddenly and uncontrollably fail. With regard to specific or local conditions, this will require a tailor-made approach. All measures to increase the flood-protection standards must be implemented before 2050. Post 2050, the flood-protection standards must be updated regularly.

\section{New urban development plans}

The decision of whether to build in low-lying flood-prone locations must be based on a cost-benefit analysis. This must reveal present and future costs for all parties. Costs resulting from local decisions must not be passed on to borne by those who benefit from these plans.

\section{Areas outside dykes}

New development in unprotected areas lying outside the dykes must not impede a river's discharge capacity or future levels of water in a lake. Residents and users themselves are responsible for such measures 
as may be needed to avoid adverse consequences. Government plays a facilitating role in such areas as public information, setting building standards and flood warnings.

\section{North Sea coast}

Until 2050, build with nature. Off the coasts of Zeeland, Holland and the Wadden Sea Islands, flood protection will be maintained by beach nourishments (see Figure 4), possibly with relocation of the tidal channels. Beach nourishments must be done in such a way that the coast can expand seaward in the next century (effectively this implies reclaiming land in the North Sea). This will provide great added value to society. Sand extraction sites in the North Sea must be reserved in the short term. The ecological, economic and energy requirements needed to nourish such large volumes must be investigated. After 2050, beach nourishments continue - more or less sand required, depending on sea level rise.

\section{Wadden Sea area}

The beach nourishments along the North Sea coast may contribute to the adaptation of the Wadden Sea area to sealevel rise. The existence of the Wadden Sea area as known at present is by no means assured, however, and depends entirely on the actual rate of sea-level rise in the coming 50-100 years. Developments will have to be monitored and analysed in an international context. The protection of the island polders and the North Holland coast must remain assured.

\section{South-western delta: Eastern Scheldt}

Until 2050, the Eastern Scheldt stormsurge barrier keeps its function. The disadvantage of the barrier is its

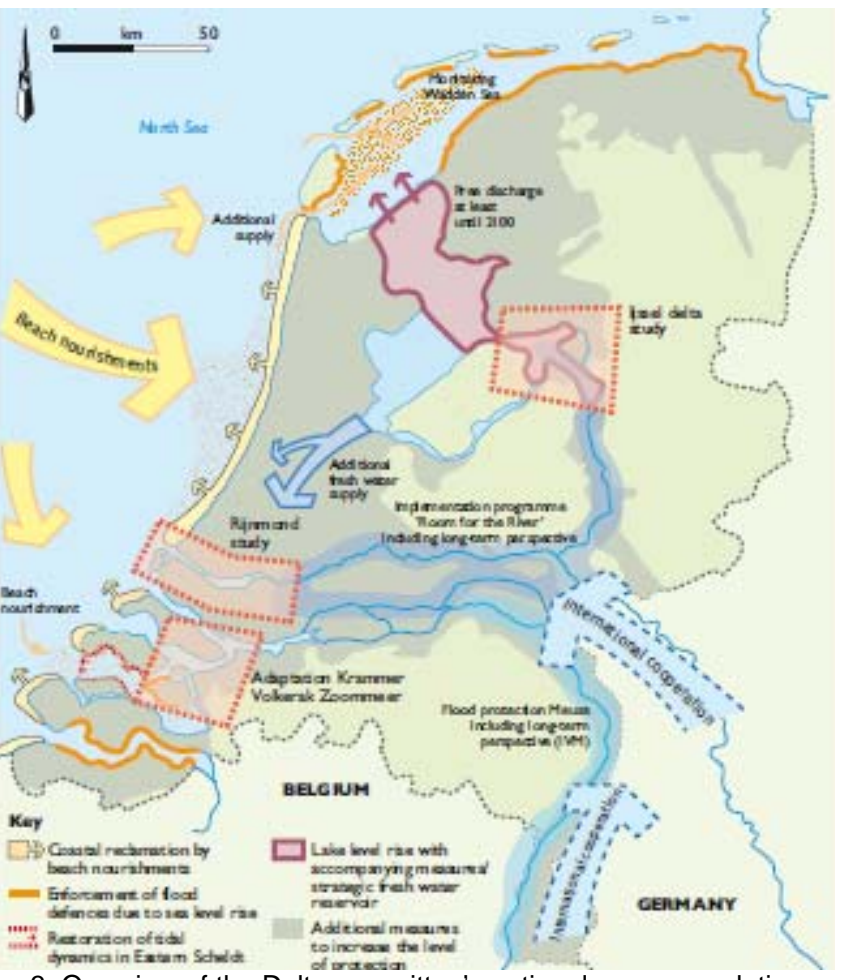

Figure 3. Overview of the Delta committee's national recommendations, which are expected to cost to $€$ 1.5-3.1 billion a year up to 2050 . restriction of tidal movement and, as a result, the loss of the intertidal zone. This is to be countered by additional sand nourishment from outside (as from the outer delta). After 2050, the life-span of the Eastern Scheldt storm-surge barrier will be extended by technical interventions. This can be done up to a sea-level rise of approximately $1 \mathrm{~m}$ (2075 at the earliest). If the Eastern Scheldt storm-surge barrier is no longer adequate, then a solution will be sought that largely restores the tidal dynamics with its natural estuarial regime, while maintaining safety against flooding.

\section{South-western delta: Western Scheldt}

This must remain an open tidal system to maintain the valuable estuary and the navigation to Antwerp. Safety against flooding must be maintained by enforcement of the dykes.

\section{South-western delta: Krammer-Volkerak Zoommeer}

Until 2050, make sure that the Krammer- Volkerak Zoommeer, together with the Grevelingen and possibly also the Eastern Scheldt, can provide temporary storage of excess water from the Rhine and Meuse when discharge to the sea is blocked by closed storm-surge barriers. A salinity gradient (a natural transition between fresh and salt water) in this area is a satisfactory solution to the water-quality problem and can offer new ecological opportunities. In this case, an alternative fresh water supply system must be developed. 


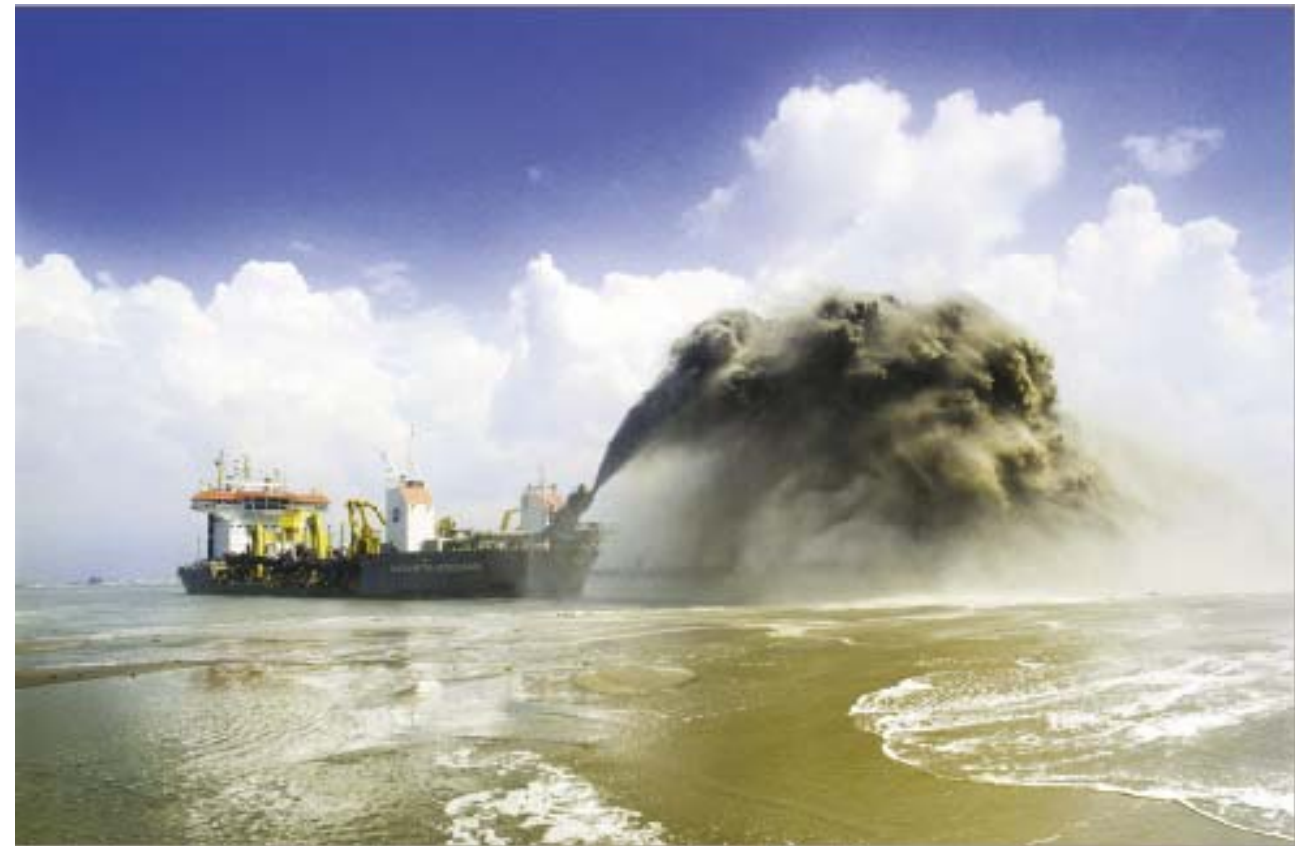

Figure 4. Beach nourishment will protect the North Sea coast as well as reclaim land for future use

\section{The major rivers area}

Until 2050, the 'Room for the river' (see Figure 5) and Maaswerken programmes must be implemented without further delays. Subject to cost-effectiveness, measures must be taken now to accommodate discharges of $18000 \mathrm{~m} 3 / \mathrm{s}$ from the Rhine and $4600 \mathrm{~m} 3 / \mathrm{s}$ from the Meuse. In this context it will be necessary to conduct negotiations with neighbouring countries under the EU directive on the assessment and management of flood risks (EC, 2007) to harmonise the measures. Furthermore, room must be reserved and, if necessary, land purchased so that the river system will be able to discharge safely the Rhine and Meuse water. From 2050 to 2100, the measures to accommodate the Rhine and Meuse discharges should be completed.

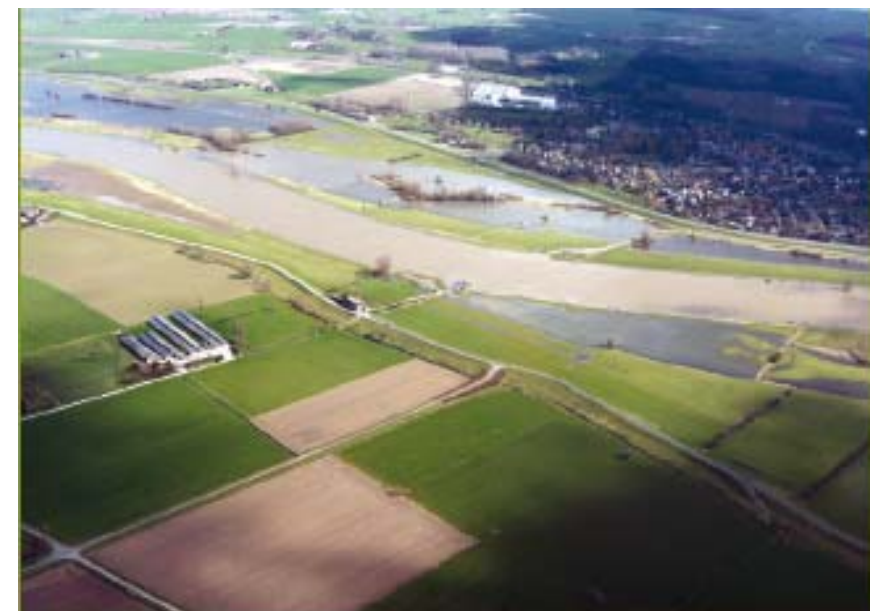

Figure. 5. Rijver ljssel is part of the 'Room for the river' programme, which is designed to accommodate an extra $226000 \mathrm{~m}^{3} / \mathrm{s}$ discharge from the Rhine and the Meuse
Rijnmond (mouth of the river Rhine)

Until 2050, this is to be an open system which can be closed in emergencies (Figure 6). It offers good prospects for combining safety against flooding, fresh water supply, urban development and nature development in the region. The extreme discharges of the Rhine and Meuse will then have to be rerouted via the south-western delta. The fresh water for the western Netherlands will have to be supplied from the Ijsselmeer, and the necessary infrastructure will have to be built. Room must be created for local storage in deep polders. Further research into the ‘closable-open' Rijnmond system should be initiated soon.

\section{IJsselmeer area}

The level of the Ijsselmeer lake will be raised by a maximum of $1.5 \mathrm{~m}$. This will allow gravity-driven drainage from IJsselmeer into the Wadden Sea beyond 2100. The level of the Markermeer lake will not be raised. The Ijsselmeer retains its strategic function as fresh water reservoir for the northern Netherlands and, in view of the progression of the salt tongue in the Nieuwe Waterweg, for the western Netherlands. Until 2050, measures should be implemented to achieve elevated water level, which can be done gradually. The aim must be to achieve the largest possible fresh water reservoir around 2050. The measures needed to adapt the lower reaches of the river IJssel and the Zwarte Water to a $1.5 \mathrm{~m}$ higher water level in the IJsselmeer must be investigated. After 2050, depending on the phased approach adopted, follow-up measures may be needed actually to implement a maximum water level increase of $1.5 \mathrm{~m}$. 
Political-administrative, legal, financial

The political-administrative organisation

of water safety should be strengthened by providing cohesive national direction and regional responsibility for execution. A permanent parliamentary committee on the theme should be implemented. Funding should be guaranteed by: creating a delta fund, managed by the minister of finance; supplying the delta fund with a combination of loans and transfer of (part of) the natural gas benefits; making national funding available and drafting rules for withdrawals from the fund. A Delta Act will anchor the

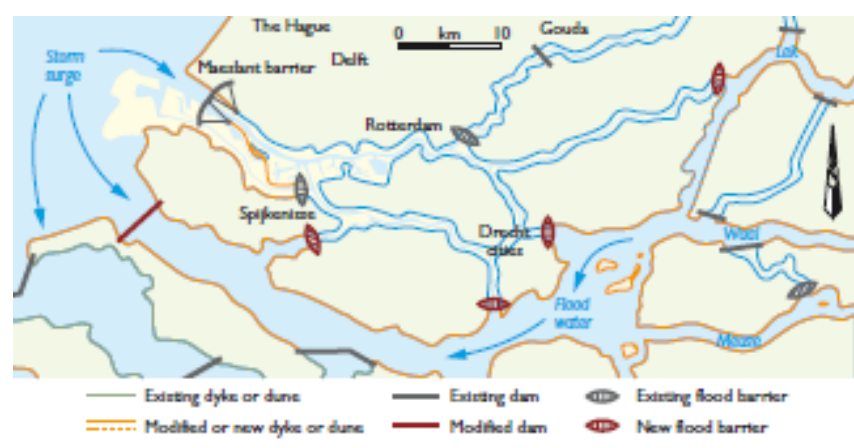

Figure 6. Rijnmond (mouth of the Rhine) will normally be open but closed in the event o storm surges and/or high river discharges using existing and new barriers to protect Rotterdam and surrounding urban areas

political-administrative organisation and funding within the present political system and the current legal framework. This must in any case include the delta fund and its supply; the director's tasks and authority; the provision that a delta programme shall be set up; regulations for strategic land acquisition; and compensation for damages or the gradual loss of benefits due to the implementation of measures under the delta programme.

\section{Costs of implementation}

Implementation of the entire package of measures proposed by the Delta committee - the Delta programme - is estimated to cost €1.2-1.6 billion a year to 2050 and $€ 0.9-1.5$ billion a year from 2050 to 2100. The summary does not include the annual sums for maintenance and management in relation to flood protection and fresh water supply. At present, these add up to approximately $€ 1.2$ billion a year for central government, the water boards and provinces. The total costs of growing with the climate and ensuring improved protection are €2.4-2.8 billion annually up to 2050 .

A supplementary $€ 0.1-0.3$ billion a year will be required if the Delta programme's beach nourishment for flood protection is expanded so that 100 years from now the North Sea coast of Holland and Zeeland is extended seawards by, for instance, $1 \mathrm{~km}$ to create new land for recreation, nature and other functions. This brings the annual costs of the programme for the period 2010-2050 to €1.3-1.9 billion, while for 2050-2100 it is $€ 1.2-1.8$ billion.

Including management and maintenance, the total costs of growing with the climate and ensuring improved protection add up to $€ 2.5-3.1$ billion a year to 2050. In absolute terms, this presents a huge monetary investment, but it translates to only about $0.5 \%$ of the current Dutch annual gross national product. The cost of integrated water safety for the future of the Netherlands is therefore far from being unbearable.

The central message of the committee is that the Netherlands can handle even the most extreme estimate of sea-level rise and river discharges that the scientific community estimates possible based upon current knowledge. The recommendations of the committee are feasible in terms of time, knowledge and economic means.

Moreover, the measures will result in more than just safety - that is, if they are implemented sensibly they will lead to more spatial quality, a more diverse nature and other socio-economic values such as balanced urban and recreation development, agriculture, fresh water supply and even possibly energy generation. And, if sea level rises slower than expected, the approach allows the flexibility to delay or temper measures and hence to adjust expenditures.

\section{Discussion and conclusions}

The Dutch Delta committee recommendations became a matter of active, often passionate public, political and academic debate. Do the recommendations sufficiently reflect highly uncertain future changes, especially in climate and sea-level rise?

The Delta committee introduced a concept of plausible high-end sea-level rise scenarios, thereby testing the feasibility of maintaining the defence strategy of the 53 dyke rings, which turned out positive both in technical and in economic terms. These go hand-in-hand with no-regret, flexible and adaptive measures: step-wise flood protection adaptation measures which can be undertaken now and which are robust enough to accommodate future insights about changing climate. An example of such measures is beach sand nourishments along the coastline to protect it from rising sea levels.

The important point is not to wait, but to start now, creating both a fund and setting up an implementation agency. It can be done - at a slower or faster pace - over many years to come, along with good monitoring of the actual rate of sea-level rise, and taking into the account the latest scenarios of sea- 
level rise and river discharge. In this way, the uncertainty which is surrounding climate scenarios is not a reason for no action at all.

The case of the Netherlands clearly illustrates that even with existing uncertainties about future climate, economically viable and responsible investments into adaptation measures in the water sector and beyond can be made. If these anticipatory interventions are flexible, they can be implemented gradually and offer prospects for action in the short term in regional planning and development. As a result, the climate issue is gradually moving from being perceived as a threat to become an opportunity. Together with innovative solutions, technologies and transitions, this presents a major opportunity to accelerate transition of the country's valuable and highly exposed Delta into a more sustainable future.

As David Wolman (2008) in Wired expressed it, 'Meanwhile, the water keeps coming. The Dutch are taking on the threat of global warming before anyone's feet are wet. They are showing the world that to prepare for sea-level rise and other impacts of climate change, you need, paradoxically, not dominion-overnature bravado but patience, good data, and - above all - the long view.'

\section{References}

Aerts J, Sprong T and Bannink B (eds) (2008) Aandacht voor Veiligheid (Attention for Safety). BSI K Klimaat voor Ruimte, DG Water, The Hague, the Netherlands, Report 009/2008 (in Dutch). See http: http://repository.tudelft.nl/view/ir/uuid\%3Aa083a598-ab79-4ce3-9861-e366dea23d6d/

Delta committee (2008) Working together with Water, Findings of the Deltacommissie. Secretariat Delta Committee, The Hague, the Netherlands. See http: http://repository.tudelft.nl/view/ir/uuid\%3A6bb16d66-94c6-44eb-bb6be389283c1e82/

EC (European Community) (2007) Directive 2007/60/EC of the European Parliament and of the Council of 23 October 2007 on the assessment and management of flood risks. Official Journal of the European Communities L288.

Hoppe R and Huijs S (2003) Werk op de Grens Tussen Wetenschap en Beleid: Paradoxen en Dilemma's (Working on the Edge Between Science and Policy: Paradoxes and Dilemmas). RMNO, The Hague, the Netherlands (in Dutch).

IPET (Interagency Performance Evaluation Taskforce) (2008) Peformance Evaluation of the New Orleans and Southeast Louisiana Hurricane Protection System. Volume 1: Executive Summary and Overview. US Army Corps of Engineers, Washington, DC, USA. See https://ipet.wes.army.mil/

Jonkman SN (2007) Loss of Life Estimation in Flood Risk Assessment - Theory and Applications. PhD thesis, Delft Technical University, Delft, the Netherlands. See http://repository.tudelft.nl/view/ir/uuid\%3Abc4fb945-55ef-4079-a606ac4fa8009426/

Jonkman SN (2008) Schattingen Groepsrisico ten behoeve van het advies Deltacommissie (Group Risk Estimates Commissioned by the Delta Committee). Royal Haskoning, Rotterdam, the Netherlands, Report 9T6387.A0/NN 0001/902968/Rott (in Dutch). See http://repository.tudelft.nl/view/ir/uuid\%3Af53bbe10-3772-492b-b25f-0fd8c4d9799b/

Jonkman SN , Stive MJF and Vrijling JK (2005) Editorial: New Orleans is a lesson to the Dutch. Journal of Coastal Research 21(6): xi-xii.

Kamphuis JW (2006) Beyond the limits of coastal engineering. In Proceedings of the 30th International Conference on Coastal Engineering (Smith J (ed.)). World Scientific, San Diego, CA , USA , pp 1938- 1950. See http: civil.queensu.ca/people/faculty/ kamphuis/publications/documents/Limits04.pdf (accessed 05/05/2011).

Katsman CA, Sterl A, Beersma J et al. (2011) Exploring high-end scenarios for local sea level rise to develop flood protection strategies for a low-lying delta - the Netherlands as an example. Climatic Change, http://dx.doi.org/10.1007/s10584-011-0037-5

Kingdom of the Netherlands (1996) Act of 21 December 1995 containing general rules to ensure protection by dikes against flooding by external water and to regulate certain related matters (Flood Defences Act). Bulletin of Acts, Orders and Decrees of the Kingdom of the Netherlands 1996, 8.

Kok M, Jonkman B, Kanning W, Rijcken T, and Stijnen J (2008) Toekomst voor het Nederlandse Polderconcept. Technische en Financiële Houdbaarheid (Future for the Dutch Polder Concept. Technical and Financial Sustainability). TU Delft, HKV-Lijn in Water, Royal Haskoning, the Netherlands (in Dutch). See http://repository.tudelft.nl/view/ir/uuid\%3Afc457df5-146d-4290-b727-4ef97d2ac0b2/

Pereira AG and Funtowicz S (2005) Quality assurance by extended peer review: tools to inform debates, dialogues \& deliberations. Technikfolgenabschätzung Theorie und Praxis 14(2): 74-79.

Saeijs HLF , Smits AJM, Overmars W and Willems D (eds) (2004) Changing Estuaries, Changing Views. Erasmus University, Rotterdam, Radboud University, Nijmegen, the Netherlands. http://repub.eur.nl/res/pub/1850/ESM-2004005.pdf

Ten Brinke WBM and Bannink BA (2004) Risico's in Bedijkte Termen, een Thematische Evaluatie van het Nederlandse Veiligheidsbeleid tegen Overstromen (Dutch Dikes and Risk Hikes, a Thematic Policy Evaluation of Risks of Flooding in the Netherlands). RIVM , Bilthoven, the Netherlands, rapport 500799002 (in Dutch). See http://www.rivm.nl/bibliotheek/rapporten/500799002.html

Van Dantzig D (1956) Economic decision problems for flood prevention. Econometrica 24(3): 276-287.

Van Tongeren D and Van de Veen P (1997) De Nationale Balans en de Overheidsbalans (The National Balance and the Government Balance). Centraal Bureau voor de Statistiek, Voorburg/ Heerlen, the Netherlands, Report P-32, M \& 0.006 (in Dutch). See http://www.cbs.nl/NR/rdonlyres/F7AEA517-5B8D-4EA5-8946-C48426F3F9E7/0/mo006.pdf

Vellinga P, Katsman CA, Sterl A et al. (2008) Exploring High-end Climate Change Scenarios for Flood Protection of the Netherlands. KNMI, De Bilt, the Netherlands, Scientific Report WR -2009-05. See http://www.knmi.nl/bibliotheek/knmipubWR/WR2009-05.pdf

Waterman RE (2008) Integrated Coastal Policy via Building with Nature, 2nd edn. Waterman, Delft, the Netherlands.

Wolman D (2008) Before the levees break: A plan to save the Netherlands. Wired 17(1). See http://www.wired.com/science/planetearth/magazine/17-01/ff dutch delta 